\title{
Hematological parameters and all-cause mortality: a prospective study of older people
}

\author{
Joanna Frąckiewicz ${ }^{1}$ - Dariusz Włodarek ${ }^{2,3}$ • Anna Brzozowska ${ }^{1}$. \\ Elżbieta Wierzbicka $^{1} \cdot$ Małgorzata Anna Słowińska $^{4} \cdot$ Lidia Wądołowska $^{4}$. \\ Joanna Kałuża ${ }^{1}$
}

Received: 26 April 2017 / Accepted: 17 June 2017 / Published online: 29 June 2017

(c) The Author(s) 2017. This article is an open access publication

\begin{abstract}
Background The effect of low and high concentration of some hematological parameters in the blood can have a negative impact on health.

Aim Therefore, we investigated the associations between hematological parameters and all-cause mortality among older people living in Poland.

Methods The study was carried out among 75-80-yearold participants $(n=403)$ from Warsaw and Olsztyn regions, Poland. Information on lifestyle factors and food consumption were obtained at baseline (June 1, 1999) using a self-administered questionnaire. Red blood cell, haemoglobin, hematocrit, mean corpuscular volume (MCV), mean corpuscular haemoglobin (MCH), and mean corpuscular haemoglobin concentration (MCHC) were determined. The data on deaths from all-causes were collected from the baseline until October 31, 2006. During an average of 7.4 years of follow-up, we ascertained 154 cases of death from all-causes.

Results Compared with men in the lowest tertile of MCV, $\mathrm{MCH}$, and MCHC, the multivariable hazard ratios (HRs) of all-cause mortality in those in the highest tertile were 0.35 (95\% CI, 0.17-0.73), 0.32 (95\% CI, 0.16-0.67), and
\end{abstract}

Joanna Frąckiewicz

joanna_frackiewicz@sggw.pl

1 Department of Human Nutrition, Warsaw University of Life Sciences-SGGW, Warsaw, Poland

2 Department of Dietetics, Warsaw University of Life Sciences-SGGW, Warsaw, Poland

3 Community Health Center Warszawa Bemowo-Włochy, Warsaw, Poland

4 Department of Human Nutrition, University of Warmia and Mazury in Olsztyn, Olsztyn, Poland
0.44 (95\% CI, 0.22-0.88), respectively. In contrast, among women after combining the second and the third tertiles of $\mathrm{MCV}, \mathrm{MCH}$, and $\mathrm{MCHC}$, the HRs were 2.01 (95\% CI, 1.01-3.99), 1.71 (95\% CI, 0.85-3.43), and 1.09 (95\% CI, $0.62-1.94)$, respectively.

Discussion/conclusion We observed inverse associations between some hematological parameters and all-cause mortality among men, but not among women. This may be explained by a difference in iron metabolism, iron status, hormone regulations, or the occurrence of some diseases.

Keywords Mortality $\cdot$ Older people $\cdot$ Hematological parameters $\cdot$ Prospective study $\cdot$ Gender

\section{Introduction}

The prevalence of anaemia increases dramatically with advancing age, reaching nearly $50 \%$ in older people, and will be increased further due to population aging [1-3]. Most anaemia cases in older individuals result from iron deficiency, chronic inflammation, chronic kidney disease, or some of them may be unexplained [4-6]. Anaemia of inflammation is one of the main types of anaemia in the geriatric population and is connected to many age-related diseases such as: obesity, cancer, chronic renal disease, etc. Even mild anaemia is related to increased mortality [7, 8]. Low haemoglobin $(\mathrm{Hb})$ concentration contributes to pathological conditions, such as poor functional status, cognitive decline and dementia, increased risk of hospitalization, morbidity, and mortality [9-12].

In contrast, a few studies have shown that a high red blood cell (RBC) count, even within the normal reference range, was strongly associated with an increased risk of allcause mortality and cardiovascular (CVD) incidence and 
mortality in middle-aged and elderly people [13-17]. The Framingham Heart Study indicated that older men with hematocrit (HTC) above 48\% compared to those with HTC $45-46 \%$ had a statistically significantly higher risk of CVD and a tendency to higher risk of coronary heart mortality [18].

Until now, most studies determined the associations between $\mathrm{Hb}$ and HTC and the risk of mortality among elderly, but did not test other hematological parameters, such as mean corpuscular volume (MCV), mean corpuscular haemoglobin (MCH) and mean corpuscular haemoglobin concentration (MCHC).

Given the inconsistent results of the studies on $\mathrm{Hb}$ and HTC and lack of studies on MCV, MCH, and MCHC and risk of morbidity and mortality among the older people, we investigated the associations of hematological parameters commonly tested by General Practitioners (GPs) with all-cause mortality in 75-80-year-old men and women living in two districts of Poland.

\section{Methods}

\section{Study design and population}

In the spring of 1999, 1200 free living respondents aged 75-80 years (born in 1914-1924) were randomly selected from the Census Bureau according to the Personal Identification Number (PESEL) by quota 600 participants from the Warsaw region and 600 from the Olsztyn region, Poland (Fig. 1). In each region, the proportion of selected men and women was 1:1 and the proportion of people living in cities, small towns, and rural areas was 1:1:1. The participation rate in the study was 54.4\% (306 men and 347

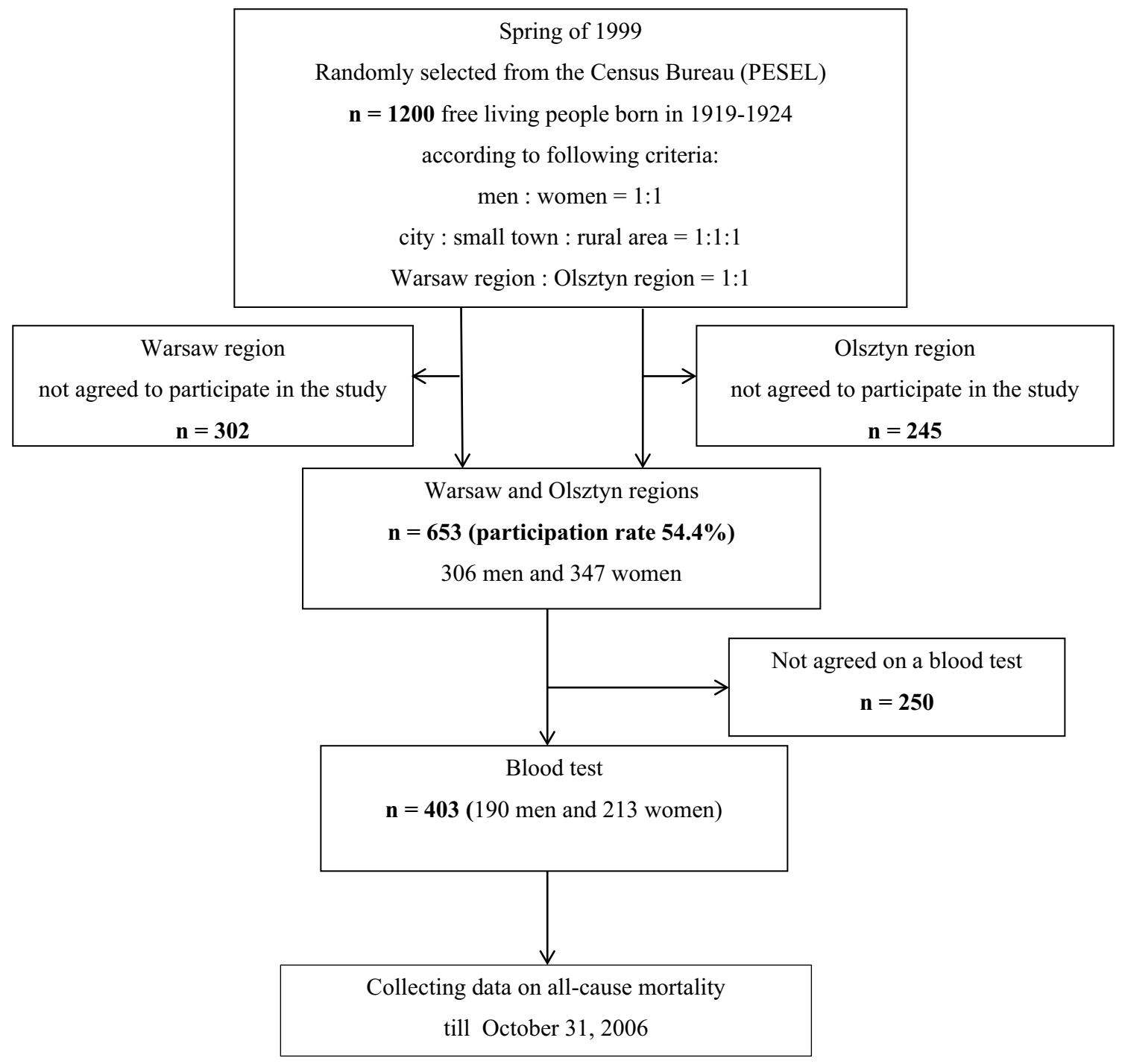

Fig. 1 Flow diagram of recruitment and participation in the study 
women). Among these participants, 403 people (190 men and 213 women) have agreed to a blood test and those people were included in the analysis. The study was approved by the Regional Ethics Commission located at the National Food and Nutrition Institute, Warsaw, Poland.

\section{Assessment of diet and other exposure}

In the spring of 1999, after a pilot study carried out among 60 participants from the Warsaw region and 60 participants from the Olsztyn region, the main study was conducted. Data on food consumption were collected using 3-day records in Warsaw and 24-h recalls in the Olsztyn region. Information on physical activity, education, smoking status, avoiding alcohol, dietary supplement use, and medicine use was obtained at baseline using a self-administered questionnaire. The body mass index (BMI) was calculated by dividing the weight $(\mathrm{kg})$ by the square of height $(\mathrm{m})$.

\section{Hematological parameters and total serum cholesterol level}

Blood parameters were determined in the medical laboratory of the National Food and Nutrition Institute in Warsaw and in the medical laboratory of the Municipal Polyclinic Hospital in Olsztyn. RBC, $\mathrm{Hb}, \mathrm{HCT}, \mathrm{MCV}, \mathrm{MCH}$, and $\mathrm{MCHC}$ in blood were determined using the Biocode Hycel Celly Hematology Analyzer (Biocode Hycel, Rennes, France) in Warsaw and the Minos analyzer (ABX, France) in Olsztyn. Total cholesterol was measured in serum using the Vitros 250 analyzer (Johnson \& Johnson Clinical Diagnostic, New Zealand) in Warsaw and the Cobas Mira E analyzer (La Roche, Switzerland) in Olsztyn.

\section{Case ascertainment}

The data on deaths from all causes were collected from June 1, 1999 until October 31, 2006. The data on deaths were obtained from the Register Offices individually for each participant.

\section{Statistical analysis}

Cox proportional hazards regression models were used to estimate hazard ratios (HRs) and 95\% confidence intervals (CIs) of all-cause mortality. We categorized participants into tertiles of $\mathrm{RBC}, \mathrm{Hb}, \mathrm{HCT}, \mathrm{MCV}, \mathrm{MCH}$, and $\mathrm{MCHC}$, separately for men and women. Among women in the result description, the second and third quartiles of hematological parameters were combined because of a relatively small number of deaths and unstable HRs.

The multivariable models included the following variables: age (continuous variable), region (Warsaw or
Olsztyn), physical activity (very low and low, or moderate and high), education (lower then higher, or higher and university), smoking status (yes or no), avoiding alcohol (yes or no), supplement use (yes or no), medicine use (yes or no), body mass index $\left(\leq 25\right.$ or $\left.>25 \mathrm{~kg} / \mathrm{m}^{2}\right)$, serum cholesterol level (tertiles), and intake of energy and iron (tertiles). The multivariable models were calculated separately for each tested hematological parameter.

To compare survival curves, the Kaplan-Meier method and the log-rank test were used. The proportional hazards' assumption was evaluated by regressing scaled Schoenfeld residuals against survival time. There was no evidence of departure from the assumption. To calculate $p$ values for trend, the median values of tertiles for $\mathrm{RBC}, \mathrm{Hb}, \mathrm{HCT}$, $\mathrm{RBC}, \mathrm{MCV}, \mathrm{MCH}$, and $\mathrm{MCHC}$ were used as a continuous variable. Using the likelihood ratio test, we tested statistical interactions between tested hematological parameters in predicting all-cause mortality according to sex, physical activity, BMI, smoking status, and avoiding alcohol.

The statistical analyses were performed using Statistica version 10.0 PL and IBM SPSS Statistics version 21. The Shapiro-Wilk test was used to check the data distribution. Average values of the tested parameters were compared using the Mann-Whitney $U$ test, while categorical data were analyzed using the $\mathrm{Chi}^{2}$ Pearson test. All reported $p$ values were two-sided, and $p$ values $\leq 0.05$ were considered as statistically significant.

\section{Results}

The mean age of participants was $77.0 \pm 1.7$ years (Table 1). Over half of the respondents were women (52.9\%) and lived in the Warsaw region (53.3\%). Most participants evaluated their physical activity as moderate or high and had primary or secondary education. Twenty percent of men and about six percent of women were current smokers, and 14 and 22\%, respectively, declared to avoid alcohol. In the past 12 months, dietary supplements and medicine were used by 41 and $72 \%$ of participants, respectively. About $73 \%$ of respondents had a BMI higher than $25 \mathrm{~kg} / \mathrm{m}^{2}$. The concentration of serum cholesterol was statistically significantly higher in women compared to men, while the intake of energy and iron was significantly lower in women.

$\mathrm{RBC}$ and concentration of $\mathrm{Hb}, \mathrm{HCT}, \mathrm{MCH}$, and $\mathrm{MCHC}$ were significantly higher among men than they were among women (Table 2). We observed a higher percentage of men compared to women with the following parameters below reference values: $\mathrm{RBC}$ (43.1 vs. $15.5 \%$, respectively), $\mathrm{Hb}$ (12.6 vs. $1.4 \%$, respectively), and HCT (27.5 vs. $16.0 \%$, respectively). At the same time, the percentage of men with MCV (21.7\%) and MCH (24.5\%) above reference values 
Table 1 Baseline characteristic of the study population (\% of the respondents)

\begin{tabular}{|c|c|c|c|c|}
\hline Variables & $\begin{array}{l}\text { Total } \\
N=403\end{array}$ & $\begin{array}{l}\text { Men } \\
N=190\end{array}$ & $\begin{array}{l}\text { Women } \\
N=213\end{array}$ & $\begin{array}{l}\text { Difference } \\
\text { between men and } \\
\text { women } \\
p \text { value }\end{array}$ \\
\hline Age (years) ${ }^{\mathrm{a}}$ & $77.0 \pm 1.7^{\mathrm{a}}$ & $77.2 \pm 1.7$ & $76.9 \pm 1.6$ & $0.071^{\mathrm{b}}$ \\
\hline \multicolumn{5}{|l|}{ Region } \\
\hline Warsaw & 53.2 & 53.2 & 53.3 & \multirow[t]{2}{*}{$0.301^{\mathrm{c}}$} \\
\hline Olsztyn & 46.8 & 46.8 & 46.7 & \\
\hline \multicolumn{5}{|l|}{ Self-reported physical activity } \\
\hline Very low or low & 29.5 & 25.3 & 33.2 & \multirow[t]{2}{*}{$0.082^{\mathrm{c}}$} \\
\hline Moderate or high & 70.5 & 74.7 & 66.8 & \\
\hline \multicolumn{5}{|l|}{ Education } \\
\hline Primary or secondary & 72.5 & 68.4 & 76.2 & \multirow[t]{2}{*}{$0.082^{c}$} \\
\hline Higher & 27.5 & 31.6 & 23.8 & \\
\hline Current smoker & 12.4 & 20.0 & 5.6 & $<0.001^{\mathrm{c}}$ \\
\hline Avoiding alcohol & 18.3 & 14.2 & 22.0 & $0.044^{\mathrm{c}}$ \\
\hline Dietary supplement use & 40.6 & 31.3 & 49.1 & $<0.001^{\mathrm{c}}$ \\
\hline Medicine use in the past 12 months & 72.0 & 66.8 & 76.6 & $0.023^{\mathrm{c}}$ \\
\hline Body mass index $\left(\mathrm{kg} / \mathrm{m}^{2}\right)^{\mathrm{a}}$ & $28.6 \pm 5.2$ & $27.4 \pm 4.0$ & $29.6 \pm 5.9$ & $0.028^{\mathrm{b}}$ \\
\hline$\leq 25$ & 26.8 & 32.1 & 21.5 & \multirow[t]{2}{*}{$0.066^{\mathrm{c}}$} \\
\hline$>25$ & 73.2 & 67.9 & 78.5 & \\
\hline Serum cholesterol $(\mathrm{mmol} / \mathrm{l})^{\mathrm{a}}$ & $5.83 \pm 1.13$ & $5.54 \pm 1.10$ & $6.08 \pm 1.09$ & $<0.001^{\mathrm{b}}$ \\
\hline Intake of energy $(\mathrm{kcal} / \mathrm{d})^{\mathrm{a}}$ & $1635 \pm 650$ & $1902 \pm 691$ & $1398 \pm 505$ & $<0.001^{\mathrm{b}}$ \\
\hline Intake of iron $(\mathrm{mg} / \mathrm{d})^{\mathrm{a}}$ & $9.06 \pm 5.23$ & $10.7 \pm 5.44$ & $7.62 \pm 4.58$ & $<0.001^{\mathrm{b}}$ \\
\hline
\end{tabular}

was higher in comparison to women $(15.1 \%$ and $13.5 \%$, respectively).

During an average of 7.4 years (3784 person-years, 1999-2006) of follow-up, we ascertained 154 cases of deaths from all-causes, including 81 deaths in men (42.6\%) and 73 deaths in women (34.3\%). This difference between men and women was not significant $(p=0.08)$.

We observed statistically significant interactions between hematological parameters $(\mathrm{MCV}$ and $\mathrm{MCH})$ and sex in relation to all-cause mortality ( $p$ for interaction: 0.004 and 0.005 , respectively); therefore, all analysis were conducted separately for men and women.

After adjusted HRs for possible confounders (multivariable HRs), we observed statistically significant inverse associations of some hematological parameters with risk of all-cause mortality among men (Table 3). Compared with men in the lowest tertile of $\mathrm{MCV}, \mathrm{MCH}$, and $\mathrm{MCHC}$, the HRs of all-cause mortality in those in the highest tertile were 0.35 (95\% CI, 0.17-0.73), 0.32 (95\% CI, 0.16-0.67) and 0.44 (95\% CI, 0.22-0.88), respectively. Among women in the second tertile versus those in the first tertile, the HR of all-cause mortality was 2.43 (95\% CI, 1.20-4.92) for MCV and 2.12 (95\% CI, 0.99-4.50) for MCH, while among women in the third tertile, the HRs were $1.44(95 \%$
CI, $0.65-3.19 \%)$ and 1.40 (95\% CI, 0.66-2.99), respectively. After combining the second and the third tertiles of $\mathrm{MCV}, \mathrm{MCH}$, and MCHC in women, the HRs were 2.01 (95\% CI, 1.01-3.99), 1.71 (95\% CI, 0.85-3.43), and 1.09 (95\% CI, 0.62-1.94), respectively. Survival curves by tertiles of $\mathrm{MCV}, \mathrm{MCH}$, and $\mathrm{MCHC}$ in the group of men and women were presented in Fig. 2. We did not observe statistically significant associations by tertiles of $\mathrm{RBC}, \mathrm{Hb}$, and HCT with all-cause mortality among men and women.

Moreover, there were no statistically significant interactions between the tested hematological parameters and the smoking status, physical activity, alcohol consumption, and BMI (all $p$-interaction $>0.1$ ).

\section{Discussion}

In this study of older people, some hematological parameters were inversely associated with a risk of all-cause mortality among men, but not among women. Men in the highest versus those in the lowest tertile of $\mathrm{MCV}, \mathrm{MCH}$, and MCHC had a statistically significant 65, 68, and 56\% lower risk of all-cause mortality, respectively. In contrast, women in the higher tertiles of MCV (the second and the third 
Table 2 Hematological parameters among 75-80-yearold participants

\begin{tabular}{|c|c|c|c|c|}
\hline Hematological parameters & Total & Men & Women & $\begin{array}{l}\text { Difference between } \\
\text { men and women } p \\
\text { value }\end{array}$ \\
\hline \multicolumn{5}{|l|}{$\operatorname{RBC}\left(10^{6} / \mu \mathrm{l}\right)$} \\
\hline Mean \pm SD & $4.46 \pm 0.49$ & $4.56 \pm 0.56$ & $4.38 \pm 0.39$ & \multirow[t]{2}{*}{$<0.001^{\mathrm{b}}$} \\
\hline Minimum-maximum & $2.19-7.45$ & $2.19-7.45$ & $3.19-5.79$ & \\
\hline \multicolumn{5}{|l|}{ Number of participants (\%) } \\
\hline$<$ Reference & 28.4 & 43.1 & 15.5 & \multirow[t]{3}{*}{$<0.001^{\mathrm{c}}$} \\
\hline Reference $^{\mathrm{a}}$ & 70.6 & 55.9 & 83.6 & \\
\hline$>$ Reference & 1.0 & 1.0 & 0.9 & \\
\hline \multicolumn{5}{|l|}{$\mathrm{Hb}(\mathrm{g} / \mathrm{dl})$} \\
\hline Mean \pm SD & $13.5 \pm 1.4$ & $14.0 \pm 1.5$ & $13.1 \pm 1.1$ & \multirow[t]{2}{*}{$<0.001^{\mathrm{b}}$} \\
\hline Minimum-maximum & $9.0-18.9$ & $9.0-18.9$ & $10.7-17.7$ & \\
\hline \multicolumn{5}{|l|}{ Number of participants (\%) } \\
\hline$<$ Reference & 6.7 & 12.6 & 1.4 & \multirow[t]{3}{*}{$<0.001^{\mathrm{c}}$} \\
\hline Reference $^{\mathrm{a}}$ & 91.3 & 84.8 & 97.2 & \\
\hline$>$ Reference & 2.0 & 2.6 & 1.4 & \\
\hline \multicolumn{5}{|l|}{$\operatorname{HCT}(\%)$} \\
\hline Mean \pm SD & $40.8 \pm 3.8$ & $41.9 \pm 4.4$ & $39.7 \pm 2.8$ & \multirow[t]{2}{*}{$<0.001^{\mathrm{b}}$} \\
\hline Minimum-maximum & $25.7-57.9$ & $25.7-57.9$ & $33.1-49.4$ & \\
\hline \multicolumn{5}{|l|}{ Number of participants (\%) } \\
\hline$<$ Reference & 21.5 & 27.5 & 16.0 & \multirow[t]{3}{*}{$0.011^{\mathrm{c}}$} \\
\hline Reference $^{\mathrm{a}}$ & 77.6 & 70.9 & 83.5 & \\
\hline$>$ Reference & 0.9 & 1.6 & 0.5 & \\
\hline \multicolumn{5}{|l|}{ MCV (fl) } \\
\hline Mean \pm SD & $91.6 \pm 6.2$ & $92.4 \pm 6.4$ & $90.0 \pm 5.9$ & \multirow[t]{2}{*}{$0.065^{\mathrm{b}}$} \\
\hline Minimum-maximum & $74.0-120.0$ & $74.0-117.0$ & $76.9-120.0$ & \\
\hline \multicolumn{5}{|l|}{ Number of participants (\%) } \\
\hline$<$ Reference & 0.5 & 1.1 & 0.0 & \multirow[t]{3}{*}{$0.069^{c}$} \\
\hline Reference $^{\mathrm{a}}$ & 81.3 & 77.2 & 84.9 & \\
\hline$>$ Reference & 18.2 & 21.7 & 15.1 & \\
\hline \multicolumn{5}{|l|}{$\mathrm{MCH}(\mathrm{pg})$} \\
\hline Mean \pm SD & $30.4 \pm 2.2$ & $30.8 \pm 2.3$ & $30.0 \pm 2.0$ & \multirow[t]{2}{*}{$0.002^{\mathrm{b}}$} \\
\hline Minimum-maximum & $21.5-40.9$ & $21.5-40.9$ & $24.6-39.7$ & \\
\hline \multicolumn{5}{|l|}{ Number of participants (\%) } \\
\hline$<$ Reference & 3.8 & 3.3 & 4.3 & \multirow[t]{3}{*}{$0.024^{c}$} \\
\hline Reference $^{a}$ & 77.6 & 72.2 & 82.2 & \\
\hline$>$ Reference & 18.6 & 24.5 & 13.5 & \\
\hline \multicolumn{5}{|l|}{$\mathrm{MCHC}(\mathrm{g} / \mathrm{dl})$} \\
\hline Mean \pm SD & $33.2 \pm 1.1$ & $33.4 \pm 1.2$ & $33.0 \pm 1.0$ & \multirow[t]{2}{*}{$0.016^{\mathrm{b}}$} \\
\hline Minimum-maximum & $29.1-36.8$ & $29.1-36.8$ & $30.2-36.1$ & \\
\hline \multicolumn{5}{|l|}{ Number of participants (\%) } \\
\hline$<$ Reference & 8.9 & 8.1 & 9.7 & \multirow[t]{3}{*}{$0.593^{\mathrm{c}}$} \\
\hline Reference $^{\mathrm{a}}$ & 91.1 & 91.9 & 90.3 & \\
\hline$>$ Reference & 0.0 & 0.0 & 0.0 & \\
\hline
\end{tabular}

$R B C$ red blood cell, $H b$ haemoglobin, $H C T$ hematocrit, $M C V$ mean corpuscular volume, $M C H$ mean corpuscular haemoglobin, $M C H C$ mean corpuscular haemoglobin concentration

${ }^{a}$ Reference values: RBC 4.5-6.5 $\times 10^{6} / \mu \mathrm{l}$ in men and 4.0-5.5 $\times 10^{6} / \mu \mathrm{l}$ in women, $\mathrm{Hb} 12.5-17.0 \mathrm{~g} / \mathrm{dl}$ in men and $11.2-15.5 \mathrm{~g} / \mathrm{dl}$ in women, HCT $40-54 \%$ in men and $37-47 \%$ in women, MCV 76-96 $\mathrm{fl}$ in men and women, $\mathrm{MCH} 27-32 \mathrm{pg}$ in men and women, MCHC 32-38 g/dl in men and women, according to laboratory reference limits

${ }^{\mathrm{b}} \mathrm{U}-$ Mann-Whitney test

${ }^{c} \chi^{2}$ Pearson test 
Table 3 Tertiles of hematological parameters in participants and Hazard Ratios (95\% confidence Intervals) of all-cause mortality

\begin{tabular}{|c|c|c|c|c|c|c|c|c|}
\hline & \multicolumn{4}{|l|}{ Men } & \multicolumn{4}{|l|}{ Women } \\
\hline & Tertile 1 & Tertile 2 & Tertile 3 & $p$ for trend & Tertile 1 & Tertile 2 & Tertile 3 & $p$ for trend \\
\hline $\begin{array}{c}\mathrm{RBC} 10^{6} / \mu \mathrm{l} \\
\text { (median) }\end{array}$ & $\leq 4.34(4.05)$ & $4.35-4.75(4.60)$ & $>4.76(4.98)$ & & $\leq 4.24(4.06)$ & $4.25-4.52(4.38)$ & $>4.53(4.74)$ & \\
\hline No. of subjects & 63 & 63 & 62 & & 73 & 69 & 71 & \\
\hline No. of cases & 25 & 26 & 30 & & 27 & 27 & 19 & \\
\hline $\begin{array}{l}\text { Age-adjusted } \\
\text { HR }\end{array}$ & 1.00 & $1.11(0.64-1.92)$ & $1.30(0.76-2.23)$ & 0.340 & 1.00 & $1.12(0.66-1.91)$ & $0.73(0.41-1.32)$ & 0.108 \\
\hline $\begin{array}{l}\text { Multivariable } \\
\mathrm{HR}^{\mathrm{a}}\end{array}$ & 1.00 & $1.54(0.75-3.18)$ & $1.38(0.65-2.91)$ & 0.550 & 1.00 & $1.21(0.65-2.25)$ & $0.70(0.36-1.36)$ & 0.208 \\
\hline $\begin{array}{l}\mathrm{Hb} \text { g/dl } \\
\text { (median) }\end{array}$ & $\leq 13.5(12.8)$ & $13.6-14.5(14.0)$ & $>14 .(15.3)$ & & $\leq 12.6(12.1)$ & $12.7-13.5(13.1)$ & $>13.6(14.2)$ & \\
\hline No. of subjects & 70 & 59 & 61 & & 71 & 81 & 61 & \\
\hline No. of cases & 36 & 24 & 21 & & 27 & 26 & 20 & \\
\hline $\begin{array}{l}\text { Age-adjusted } \\
\text { HR }\end{array}$ & 1.00 & $0.75(0.44-1.26)$ & $0.59(0.34-1.01)$ & 0.105 & 1.00 & $0.90(0.52-1.54)$ & $0.94(0.52-1.68)$ & 0.999 \\
\hline $\begin{array}{l}\text { Multivariable } \\
\mathrm{HR}^{\mathrm{a}}\end{array}$ & 1.00 & $0.82(0.42-1.60)$ & $0.68(0.35-1.33)$ & 0.141 & 1.00 & $1.03(0.54-1.96)$ & $0.93(0.49-1.78)$ & 0.871 \\
\hline $\begin{array}{l}\text { HCT \% } \\
\text { (median) }\end{array}$ & $\leq 40.5(38.4)$ & $40.6-43.3(41.9)$ & $>43.4(45.5)$ & & $\leq 38.5(37.1)$ & $38.6-40.7(39.5)$ & $>40.8(42.4)$ & \\
\hline No. of subjects & 65 & 62 & 62 & & 72 & 70 & 70 & \\
\hline No. of cases & 32 & 23 & 26 & & 27 & 24 & 22 & \\
\hline $\begin{array}{l}\text { Age-adjusted } \\
\text { HR }\end{array}$ & 1.00 & $0.72(0.42-1.24)$ & $0.77(0.46-1.29)$ & 0.500 & 1.00 & $0.92(0.53-1.60)$ & $0.89(0.51-1.56)$ & 0.984 \\
\hline $\begin{array}{l}\text { Multivariable } \\
\mathrm{HR}^{\mathrm{a}}\end{array}$ & 1.00 & $0.86(0.43-1.72)$ & $0.77(0.38-1.56)$ & 0.436 & 1.00 & $0.90(0.47-1.73)$ & $0.76(0.39-1.45)$ & 0.636 \\
\hline $\begin{array}{l}\text { MCV fl } \\
\text { (median) }\end{array}$ & $\leq 89.7(87.0)$ & $89.8-94.8$ (91.6) & $>94.9(98.0)$ & & $\leq 88.0(86.3)$ & $88.1-92.0(90.3)$ & $>92.1(96.0)$ & \\
\hline No. of subjects & 64 & 62 & 63 & & 71 & 71 & 70 & \\
\hline No. of cases & 34 & 25 & 21 & & 16 & 31 & 26 & \\
\hline $\begin{array}{l}\text { Age-adjusted } \\
\text { HR }\end{array}$ & 1.00 & $0.69(0.41-1.15)$ & $0.49(0.29-0.85)$ & 0.005 & 1.00 & $1.99(1.08-3.64)$ & $1.64(0.88-3.06)$ & 0.007 \\
\hline $\begin{array}{l}\text { Multivariable } \\
\mathrm{HR}^{\mathrm{a}}\end{array}$ & 1.00 & $0.66(0.35-1.21)$ & $0.35(0.17-0.73)$ & 0.010 & 1.00 & $2.43(1.20-4.92)$ & $1.44(0.65-3.19)$ & 0.117 \\
\hline $\begin{array}{l}\mathrm{MCH} \text { pg } \\
\text { (median) }\end{array}$ & $\leq 30.0(29.1)$ & $30.1-31.5(30.8)$ & $>31.6(32.5)$ & & $\leq 29.3(28.9)$ & $29.4-30.7(30.0)$ & >30.8 (31.8) & \\
\hline No. of subjects & 65 & 58 & 61 & & 71 & 69 & 68 & \\
\hline No. of cases & 37 & 24 & 18 & & 17 & 30 & 25 & \\
\hline $\begin{array}{l}\text { Age-adjusted } \\
\text { HR }\end{array}$ & 1.00 & $0.64(0.39-1.08)$ & $0.43(0.24-0.75)$ & $<0.001$ & 1.00 & $1.82(1.00-3.31)$ & $1.55(0.84-2.87)$ & 0.026 \\
\hline $\begin{array}{l}\text { Multivariable } \\
\mathrm{HR}^{\mathrm{a}}\end{array}$ & 1.00 & $0.67(0.34-1.31)$ & $0.32(0.16-0.67)$ & 0.001 & 1.00 & $2.12(0.99-4.50)$ & $1.40(0.66-2.99)$ & 0.139 \\
\hline $\begin{array}{l}\text { MCHC g/ } \\
\text { dl(median) }\end{array}$ & $\leq 32.8(32.3)$ & $32.9-33.7(33.3)$ & $>33.8$ (34.6) & & $\leq 32.5(32.1)$ & $32.6-33.2(32.9)$ & $>33.3(34.0)$ & \\
\hline No. of subjects & 66 & 60 & 59 & & 73 & 65 & 69 & \\
\hline No. of cases & 38 & 23 & 18 & & 27 & 17 & 28 & \\
\hline $\begin{array}{l}\text { Age-adjusted } \\
\text { HR }\end{array}$ & 1.00 & $0.58(0.35-0.98)$ & $0.46(0.26-0.80)$ & 0.010 & 1.00 & $0.60(0.33-1.10)$ & $1.00(0.59-1.70)$ & 0.854 \\
\hline
\end{tabular}


Table 3 (continued)

\begin{tabular}{|c|c|c|c|c|c|c|c|c|}
\hline & \multicolumn{4}{|l|}{ Men } & \multicolumn{4}{|l|}{ Women } \\
\hline & Tertile 1 & Tertile 2 & Tertile 3 & $p$ for trend & Tertile 1 & Tertile 2 & Tertile 3 & $p$ for trend \\
\hline $\begin{array}{l}\text { Multivariable } \\
\text { HR }^{\mathrm{a}}\end{array}$ & 1.00 & $0.63(0.34-1.18)$ & $0.44(0.22-0.88)$ & 0.032 & 1.00 & $0.82(0.42-1.61)$ & $1.60(0.81-3.17)$ & 0.398 \\
\hline
\end{tabular}

$R B C$ red blood cell, $H b$ haemoglobin, $H C T$ hematocrit, $M C V$ mean corpuscular volume, $M C H$ mean corpuscular haemoglobin, $M C H C$ mean corpuscular haemoglobin concentration

${ }^{a}$ Multivariable model adjusted for age (continuous variable), region (Warsaw or Olsztyn), physical activity (very low and low, or moderate and high), education (primary or secondary, or higher), smoking status (yes or no), avoiding alcohol (yes or no), supplement use (yes or no), medicine use (yes or no), body mass index ( $\leq 25$ or $>25 \mathrm{~kg} / \mathrm{m}^{2}$ ), serum cholesterol level (tertiles), and intake of energy and iron (tertiles)
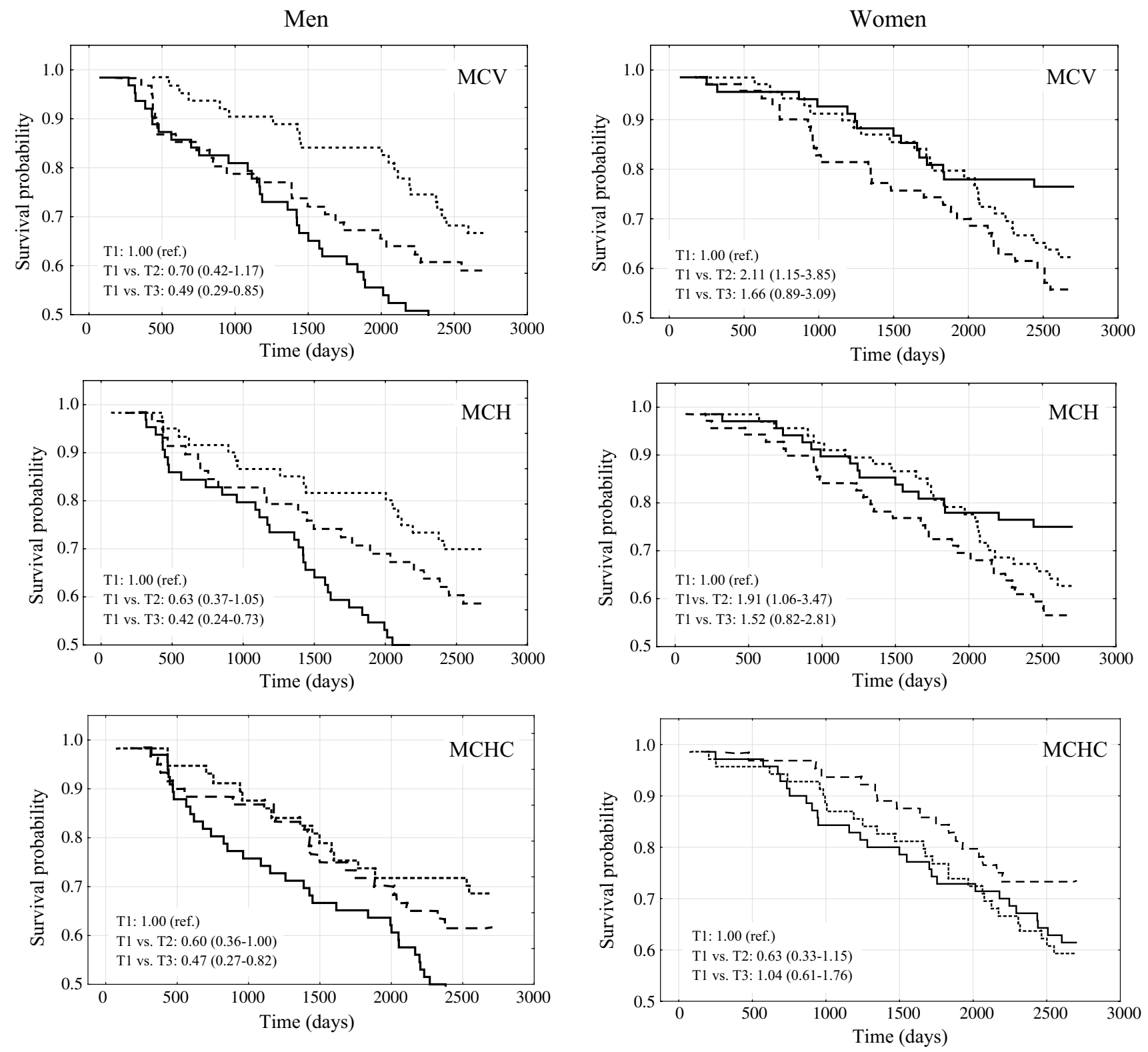

Tertile $1(\mathrm{~T} 1)$

- - - Tertile $2(\mathrm{~T} 2)$

Tertile 3 (T3)

Fig. 2 Survival curves for MCV, MCH, and MCHC among men and women. Solid line Tertile 1 (T1), dashed line Tertile 2 (T2), dotted line Tertile 3 (T3) 
tertiles combined) in comparison to those in the first tertile had a twofold higher risk of all-cause mortality. No similar associations were observed for $\mathrm{RBC}, \mathrm{Hb}$, and HCT. Moreover, in our previous study in the same population of men and women, we observed that women with iron serum concentration above the median had a statistically significantly fourfold (HR: 4.10; 95\% CI: 1.16-14.5) higher risk of allcause mortality than those with lower iron serum concentration. In men, a similar association was not observed [19].

To the best of our knowledge, there are no previously published studies on $\mathrm{MCV}, \mathrm{MCH}$, and $\mathrm{MCHC}$ in relation to all-cause and specific-cause mortality. Most epidemiological studies have investigated the association between $\mathrm{Hb}[9,20-23]$ and HCT [24-26] and the risk of all-cause mortality [9, 20-23] and CVD mortality [23-26] among people aged 55 years and older. The HRs of all-cause mortality increased from 33\% in men and women with low $\mathrm{Hb}$ concentration to twofold in people with mild anaemia and sixfold in those with moderate and severe anaemia [23]. Results of a large prospective cohort study $(n=49,983)$ indicate a U-shape relationship between HCT and all-cause and CVD mortality in women; low and high values of HCT were associated with higher risk of death [24]. In addition, in a case-control study HCT $\geq 50 \%$ resulted in an $80 \%$ higher risk of coronary heart disease (CHD) mortality in men [22]. No similar associations between HCT and CHD were observed in the Second National Health and Nutrition Examination Survey [26].

In our study, we did not find any significant associations between $\mathrm{Hb}$ and HCT and all-cause mortality among men and women. However, among men, the HRs were 32 and $23 \%$ lower in the third tertile compared to the first tertile of $\mathrm{Hb}$ and $\mathrm{HCT}$, respectively, while among women, the HR was $24 \%$ lower only for HCT. These results are consistent with the percentage of people below reference levels for these parameters. We suppose that the lack of a significant impact of $\mathrm{Hb}$ on all-cause mortality was a result of a small number of anemic women in our study (1.4\% of women) and a relatively low percentage of anemic men (12.6\%).

We can speculate that the gender differences in the presented results can depend on different iron metabolism and iron status as well as different hormone regulations and health condition. It is known that androgen and estrogen concentrations may play an important role in erythro- and myelopoiesis processes [27]. Based on a clinical trial, it was observed that a testosterone-induced increase in $\mathrm{Hb}$ and HCT was associated with stimulation of erythropoietin and reduced ferritin and hepcidin concentrations among elderly men [28]. Moreover, high risk of all-cause mortality among women may be caused by a potential adverse effect of iron. It is known that an excess of iron has pro-inflammatory and pro-oxidative properties $[29,30]$. By catalysing the formation of free radicals, high levels of iron may lead to lipid peroxidation [31-33], protein, and DNA modifications [33, 34]. It was observed that $\mathrm{MCH}$ and $\mathrm{MCHC}$ were inversely correlated with C-reactive protein [35], and $\mathrm{MCHC}$ was associated with carotid intima media thickness and with interleukin-6 (IL-6) among hypertensive patients [36]. It seems feasible that the observed lower mortality in men in the highest versus those in the lowest tertile of MCV may be related to the level of red cell distribution width (RDW). It has been shown that the level of RDW inversely correlated with MCV $[15,37]$ and higher RDW is a strong predictor of all-cause mortality in adults of 45 and older $[15,38]$ as well as in older people with and without ageassociated diseases [38].

The major strengths of the present study were the broad use of hematology parameters, a random selection of people from two different districts of Poland as well as data collection in both regions based on the same questionnaires. We adjusted the Cox proportional hazard models for the main potential confounders, which could affect the final results; however, we were not able to rule out residual or unmeasured confounding. The main limitation of this study was a relatively small number of participants and instances of death from all-causes. People who refused to participate in the study were characterized by a worse health status than those who took part; thus, the study population was healthier than the older Polish public. Another limitation of the study was the lack of data on the ferritin, transferrin receptor concentrations, and red cell distribution width as well as inflammation markers. Parameters such ferritin and transferrin receptor concentrations are more specific to determine iron status; however, hematological parameters are commonly examined in older people by GPs and they are useful prognostic factors of morbidity and mortality.

\section{Conclusions}

The findings from this prospective study indicate that some hematological parameters were inversely associated with the risk of all-cause mortality among older men, but not among women. The differences in the results between genders can be explained by different iron metabolism, iron status, and hormone regulations among men and women, and also by the occurrence of diseases, which can have an impact on hematological parameters. This finding warrants confirmation in further prospective studies conducted on a bigger population.

Acknowledgements We are grateful to Prof. Wojciech Roszkowski from the Department of Human Nutrition WULS-SGGW for general support. 


\section{Compliance with ethical standards}

Conflict of interest None of the authors have any potential conflicts of interest to declare.

Human and animal rights All procedures performed in studies involving human participants were in accordance with the ethical standards of the institutional and/or national research committee and with the 1964 Helsinki declaration and its later amendments or comparable ethical standards.

Informed consent Informed consent was obtained from all individual participants included in the study.

Open Access This article is distributed under the terms of the Creative Commons Attribution 4.0 International License (http:// creativecommons.org/licenses/by/4.0/), which permits unrestricted use, distribution, and reproduction in any medium, provided you give appropriate credit to the original author(s) and the source, provide a link to the Creative Commons license, and indicate if changes were made.

\section{References}

1. Tettamanti M, Lucca U, Gandini F et al (2010) Prevalence, incidence and types of mild anemia in the elderly: the "Health and Anemia" population-based study. Haematologica 95:1849-1856

2. Gaskell H, Derry S, Andrew Moore R et al (2008) Prevalence of anemia in older persons: systematic review. BMC Geriatr 8:1

3. Guralnik JM, Eisenstaedt RS, Ferrucci L et al (2004) Prevalence of anemia in persons 65 years and older in the United States: evidence for a high rate of unexplained anemia. Blood 104:2263-2268

4. Eisenstaedt R, Penninx BWJH, Woodman RC (2006) Anemia in the elderly: current understanding and emerging concepts. Blood Rev 20:213-226

5. Izaks GJ, Westendorp RG, Knook DL (1999) The definition of anemia in older persons. JAMA 281:1714-1717

6. Ania BJ, Suman VJ, Fairbanks VF et al (1997) Incidence of anemia in older people: an epidemiologic study in a well defined population. J Am Geriatr Soc 45:825-831

7. Turusheva A, Frolova E, Hegendoerfer E et al (2016) Predictors of short-term mortality, cognitive and physical decline in older adults in northwest Russia: a population-based prospective cohort study. Aging Clin Exp Res. doi:10.1007/ s40520-016-0613-7

8. Semba RD, Ricks MO, Ferrucci L et al (2007) Types of anemia and mortality among older disabled women living in the community: the Women's Health and Aing Study I. Aging Clin Exp Res 19:259-264

9. den Elzen WPJ, Willems JM, Westendorp RGJ et al (2009) Effect of anemia and comorbidity on functional satus and mortality in old age: results from the Leiden 85-plus Study. CMAJ 181:151-157

10. Riva E, Tettamanti M, Mosconi P et al (2009) Association of mild anemia with hospitalization and mortality in the elderly: The Health and Anemia population-based study. Haematologica 94:22-28

11. Patel KV (2008) Epidemiology of anemia in older adults. Semin Hematol 45:210-217
12. Peters R, Burch L, Warner J et al (2008) Haemoglobin, anemia, dementia and cognitive decline in the elderly, a systematic review. BMC Geriatr 8:18

13. Cavusoglu E, Chopra V, Gupta A et al (2010) Relation between red blood cell width (RDW) and all-cause mortality at 2 years in an unselected population referred for coronary angiography. Int J Cardiol 141:141-146

14. Ani C, Ovbiagele B (2009) Elevated red blood cell distribution width predicts mortality in persons with known stroke. J Neurol Sci 277:103-108

15. Patel KV, Ferrucci L, Ershelr WB et al (2009) Red cell distribution width and the risk of death in middle-age and older adults. Arch Intern Med 169:515-523

16. Perlstein TS, Wenve J, Pfeffer MA et al (2009) Red blood cell distribution width and mortality risk in a community-based prospective cohort. Arch Intern Med 169:588-594

17. Tonelli M, Sacks F, Arnold M et al (2008) Relation between red blood cell distribution width and cardiovascular event rate in people with coronary disease. Circulation 117:163-168

18. Ganon DR, Zhang TJ, Brand FN et al (1994) Hematocrit and the risk of cardiovascular disease-the Framingham Study: a 34-year follow-up. Am Heart J 127:674-682

19. Kaluza J, Jeruszka-Bielak M (2006) The relationship between iron nutritional status and mortality among older people from the Warsaw region. Polish J Environ Sud 15:329-335

20. De la Cruz-Góngora V, Manrique-Espinoza B, Villalpando S et al (2014) Short-term impact of anemia on mortality: evidence from a sample of Mexican older adults. J Aging Health 26:750-765

21. Shavelle RM, MacKenzie R, Paculdo DR (2012) Anemia and mortality in older persons: does the type of anemia affect survival? Int J Hematol 95:248-256

22. Landi F, Russo A, Danese P et al (2007) Anemia status, hemoglobin concentration, and mortality in nursing home older residents. J Am Med Dir Assoc 8:322-327

23. Zakai NA, Kaiz R, Hirsch C et al (2005) A prospective study of anemia status, hemoglobin concentration, and mortality in an elderly cohort. Arch Intern Med 165:2214-2220

24. Boffetta P, Islami F, Vedanthan R et al (2013) A U-shaped relationship between haematocrit and mortality in a large prospective cohort study. Int J Epidemiol 42:601-615

25. Kunnas T, Solakivi T, Huuskonen K et al (2009) Hematocrit and the risk of coronary heart disease mortality in the TAMRISK study, a 28-year follow-up. Prev Med 49:45-47

26. Brown DW, Giles WH, Croft JB (2001) Hematocrit and the risk of coronary heart disease mortality. Am Heart J 142:657-663

27. Ikeda Y, Tajima S, Izawa-Ishizawa Y et al (2012) Estrogen regulates hepcidin expression via GPR30-BMP-dependent signaling in hepatocytes. PLoS One 7:e40465

28. Bachman E, Travison TG, Basaria S et al (2014) Testosterone induces erythrocitosis via increased erythropoietin and suppressed hepcidin: evidence for a new erythropoietin/hemoglobin set point. J Gerontol A Biol Sci Med Sci 69:725-735

29. Jamova K, Valko M (2011) Advances in metal-induced oxidative stress a human disease. Toxicology 283:65-87

30. Selim MH, Ratan RR (2004) The role of iron neurotoxicity in ischemic stroke. Ageing Res Rev 3:345-353

31. King SM, Donangelo CM, Knutson MD et al (2008) Daily supplementation with iron increases lipid peroxidation in young women with low iron stores. Exp Biol Med (Maywood) 233:701-707

32. Lasheras C, Gonzales S, Huerta JM et al (2003) Plasma iron is associated with lipid peroxidation in an elderly population. $\mathrm{J}$ Trace Elem Med Biol 17:171-176 
33. Zago MP, Verstraeten SV, Oteiza PI (2000) Zinc in the prevention of $\mathrm{Fe}_{2}{ }^{+}$-initiated lipid and protein oxidation. Biol Res 33:143-150

34. Hori A, Mizoue T, Kasai $\mathrm{H}$ et al (2010) Body iron store as a predictor of oxidative DNA damage in healthy men and women. Cancer Sci 101:517-522

35. Okada Y, Takahashi A, Ohmiya H et al (2011) Genomewide association study for C-reactive protein levels identified pleiotropic associations in the IL6 locus. Hum Mol Genet 20:1224-1231

36. Fornal M, Wizner B, Cwynar M et al (2014) Association of red blood cell distribution width, inflammation markers and morphological as well as rheological erythrocyte parameters with target organ damage in hypertension. Clin Hemorheol Microcirc 56:325-335

37. Hsieh YP, Chang CC, Kor CT et al. (2016) The predictive role of red cell distribution width in mortality among chronic kidney disease patients. PLoS ONE 11:e0162025. doi:10.1371/journal. pone. 0162025

38. Patel KV, Semba RD, Ferrucci L et al (2010) Red cell distribution width and mortality in older adults: a meta-analysis. J Gerontol A Biol Sci Med 65A: 258-266 